\title{
Characterization of the Biomass of a Hybrid Anaerobic Reactor (HAR) with Two Types of Support Material During the Treatment of the Coffee Wastewater
}

\author{
Vivian Galdino da Silva ${ }^{1}$, Cláudio Milton Montenegro Campos $^{2}$, Erlon Lopes Pereira ${ }^{3 *}$ and \\ Júlia Ferreira da Silva ${ }^{4}$ \\ ${ }^{1}$ Unidade de Ciências Exatas e Tecnológicas; Universidade Estadual de Goiás; CP.:459; Goiânia - GO - Brasil. \\ ${ }^{2}$ Departamento de Engenharia; Setor Recursos Hídricos e Meio Ambiente; Universidade Federal de Lavras; CP.: \\ 3037; Lavras - MG - Brasil . . Departamento de Biotecnologia Industrial; Escola de Engenharia de Lorena; \\ Universidade de São Paulo; Lorena - SP - Brasil. ${ }^{4}$ Instituto de Ciências Ambientais e Desenvolvimento Sustentável; \\ Universidade Federal da Bahia; Barreiras - BA - Brasil
}

\begin{abstract}
This study investigated the microbiology of a hybrid anaerobic reactor (HAR) in the removal of pollutant loads. This reactor had the same physical structure of an UASB reactor, however with minifilters inside containing two types of support material: expanded clay and gravel. Two hydraulic retention times (HRT) of $24 \mathrm{~h}$ and $18 \mathrm{~h}$ were evaluated at steady-state conditions, resulting in organic loading rates (OLR) of 0.032 and $0.018 \mathrm{kgDBO}_{5} \mathrm{~m}^{-3} \mathrm{~d}^{-1}$ and biological organic loading rates (BOLR) of 0,0015 and $0.001 \mathrm{kgDBO}_{5} \mathrm{kgSVT}^{-1} \mathrm{~d}^{-1}$, respectively. The decrease in concentration of organic matter in the influent resulted an endogenous state of the biomass in the reactor. The expanded clay was the best support material for biofilm attachment.
\end{abstract}

Key words: Agricultural microbiology, endogenous, anaerobic process, agro-industrial wastewater treatment, rural sanitation

\section{INTRODUCTION}

The wet processing of coffee produces a better quality of coffee. The process is being currently explored for improvement to avoid the negative effects on product quality and reduce energy consumption (Campos et al. 2010). A large amount of water is used during the washing and peeling of the fruits. The resulting wastewater is quite rich in organic and inorganic materials, and therefore, must be treated before being released into water bodies (Prado and Campos 2008).

The effluent treatment processes can be classified as physical, chemical and biological. Biological processes are mainly used to remove the biodegradable organic substances, which become a food source for the microorganism (Torres et al. 2003). According to Pereira et al. (2009), Pereira et al. (2010a), Pereira et al. (2010b) and, Pereira et al. (2011), the essence of biological wastewater treatment lies in the ability of the microorganisms involved to use the biodegradable organic compounds, transforming them into products, which can be removed in the treatment system. The efficiency of the anaerobic process depends on the interactions between the species of microorganisms with different capabilities to degrade various substrates. This also depends on their ability to acclimatize and develop a high

*Author for correspondence: erlonlopes@gmail.com 
microbial activity and capacity to bear the hydraulic and biological shocks (Pereira et al. 2009). Therefore, an evaluation of the specific methanogenic activity (SMA) of an anaerobic sludge becomes an important analysis for monitoring the process (Chaiprasert et al. 2003).

The upflow anaerobic sludge blanket reactor (UASB) has difficulties in producing an effluent that accomplishes within the standards set by the environmental legislation. Thus, it becomes important to apply some form of post-treatment to its effluent, in order to make the treated wastewater meet legal requirements and adequately protect the receiving water bodies (Pereira et al. 2010a). Anaerobic filters are among the alternatives of post-treatments. These filters are characterized by the presence of a stationary packing material, to which the bacteria can stick to form the biofilm and also, in the interstices, the biomass can grow loosely but with a good capacity of removing additional organic matter (Fia et al. 2010; Silva et al. 2010; Silva et al. 2011b).

Among the anaerobic filters, the hybrid anaerobic reactors (HAR) have the structure of a UASB reactor; however, their bed is composed of composite material in order to support the biofilm formation. This technology is still developing rapidly and its various configurations allow great flexibility in design and construction with regard to the shape, direction of flow and support material (Chaiprasert et al. 2003). The purpose of the support material is to retain the bacterial biofilm within the reactor, serving also as a device for separating the solids from the gases, helping to promote a uniform flow in the reactor, improving the contact between the organic constituents of the influent and microorganisms in the biofilm and interstitial forms. This process allows the accumulation of large amounts of biomass, with the consequent increase in cellular retention time, and also acting as a physical barrier, preventing the solids to be washed out from the treatment system (Omil et al. 2003).

As explained before, the retention of biomass around the support material forms a biologically active structure, called biofilm, and the microorganisms that are not able to stay in the biofilm, form a type of interstitial flocculent or granular sludge inside the interstices. This interstitial sludge is biologically active and if withdrawn from the system, can affect the efficiency negatively.

As coffee is an annual crop, usually at the end of the harvest, there is reduction in the effluent concentration due to reduced discharge. This fact does reduce the concentration of biomass due to inbreeding occurred in the system. This study aimed at evaluating the process of endogenous in a hybrid anaerobic reactor (HAR) treating the wastewater from coffee wet process (WCWP) using two types of support material. The study included the effect of operating parameters on the endogenous process by assessing the microbiological response using a scanning electron microscopy and epi-fluorescence microscopy and followed the process parameters as described by Silva et al. (2011b).

\section{MATERIALS AND METHODS}

\section{The Hybrid Anaerobic Reactor}

The hybrid anaerobic reactor (HAR) was made using the polyester with catalyst orthophthalic resin and, subsequently, capped with roving fiber reinforced with steel rings and covered with orthophthalic gel-coat (Fig. 1b). The unit had a diameter of $1.0 \mathrm{~m}$, height of $4.0 \mathrm{~m}$ and volume of 3,107 L (Fig. 1a). Also, there was a three-phase separator (TPS) with a height of $1.37 \mathrm{~m}$, built of fiberglass (Figures 1c and 1d). A nylon screen was adapted to the TPS in order to avoid the minifilters to occupy its inner space (Fig. 1d).

Inside the HAR, 54 minifilters, constructed of Vinyl polychloride (CPV- $1 \mathrm{~m}$ long and $0.1 \mathrm{~m}$ in diameter) were placed. This quantity was determined according to the diameter of the reactor. These minifilters contained expanded clay and rolled pebble. Four days after the end of the harvest, the minifilters were placed in the HAR, after being defined by means of experimental tests, the ratio between the resources expanded clay and rolled pebble (Silva et al. 2010). 

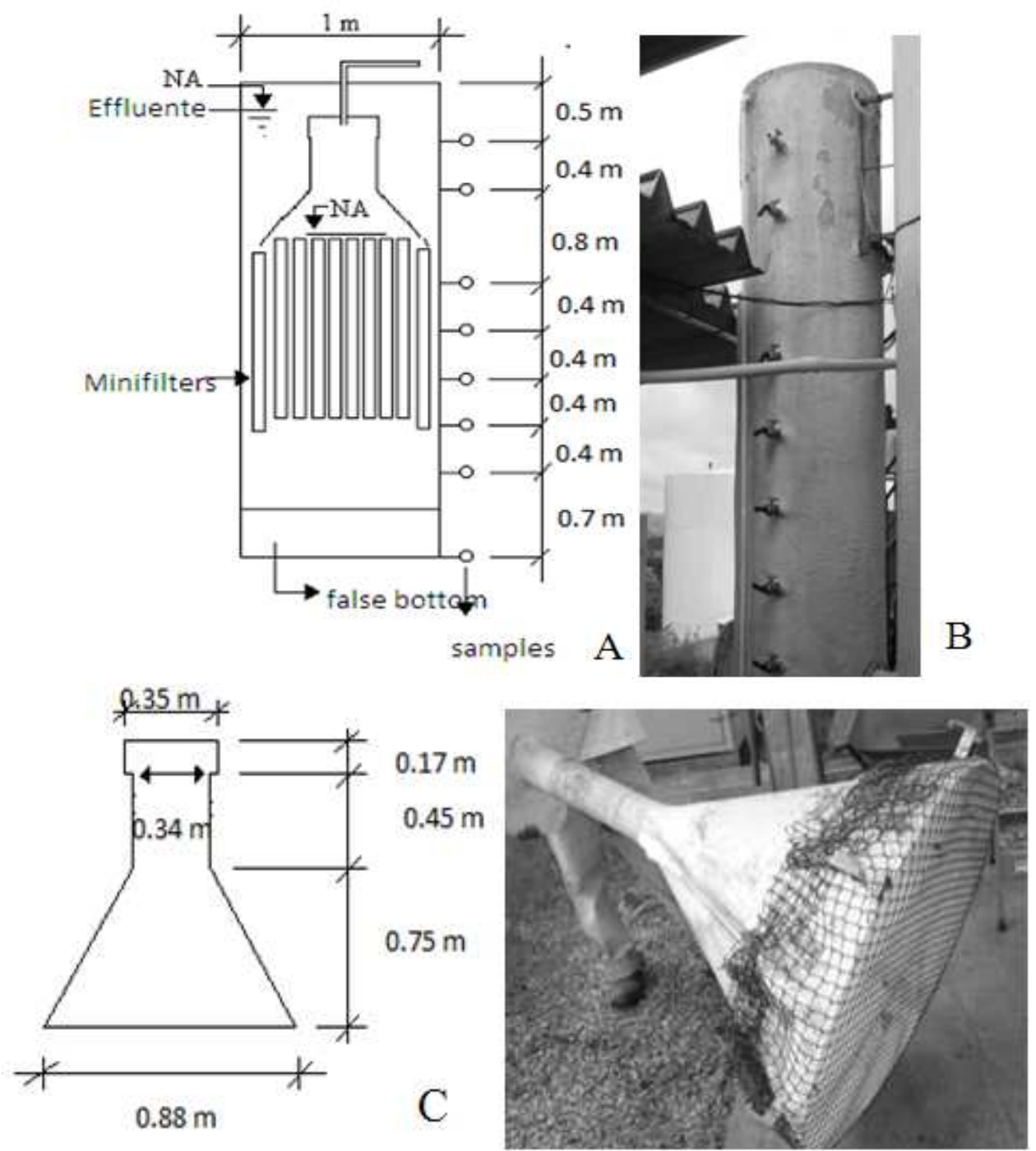

Figure 1 - Hybrid Anaerobic Reactor (HAR) located in CCRCC / UFLA. (A) Longitudinal section. (B) Partial view. (C) Longitudinal section of TPS. (D) TPS with a nylon screen.

\section{Start up of the System and Steady State: Operational Control System}

The experiment was conducted at the pilot sewer treatment system located at Coffee Center for Research on Coffee Culture (CCRCC), in the Agriculture Department, Federal University of Lavras (UFLA). The system was composed with preliminary treatment, with screen, sand sedimentation tank, secondary treatment composed by a stabilization pond (SP), two concentric UASB reactors (R1 UASB and R2 UASB) working in series with an equalization pressure tank, an HAR, three filters for $\mathrm{H}_{2} \mathrm{~S}$ removing, three gas-meters, two aerobic batch reactors (ABR), a drainage bed sludge (DBS), six reservoirs $\left(\mathrm{T}_{1,2,3} \ldots\right)$ and a pumping system with six pumps (Fig. 2).
The COD and $\mathrm{BOD}_{5}$ of the effluent of stabilization pond and also the profile of solids digestion compartments of R1 and the RAH were analysed, in order to determine the load for start-up according to the HRT. On the $24^{\text {th }}$ day of the experiment, several adjustments in the Leder program of the PLC were made and also exchanged some solenoid valves. It was further monitored for the $\mathrm{pH}$, conductivity, salinity, total dissolved solids, and also COD and $\mathrm{BOD}_{5}$. More details concerning the flow control, $\mathrm{pH}$, alkalinity, temperature and other control parameters can be found in Silva et al. (2010). The system was monitored daily for the influent and effluent temperature, ambient temperature, relative humidity, $\mathrm{pH}$, electric conductivity (EC), salinity 
and total dissolved solids (TDS). At predetermined intervals, $\mathrm{COD}, \mathrm{BOD}_{5}{ }^{20^{\circ} \mathrm{C}}$, total solids (TS), total fixed solids (TFS), total volatile solids (TVS), and total alkalinity (TA), partial alkalinity (PA) and intermediate alkalinity (IA) were analyzed. Periodically, the samples were collected from the profile of the reactor to determine the concentrations of total, fixed and volatile solids. The analysis were conducted following the APHA (2005).

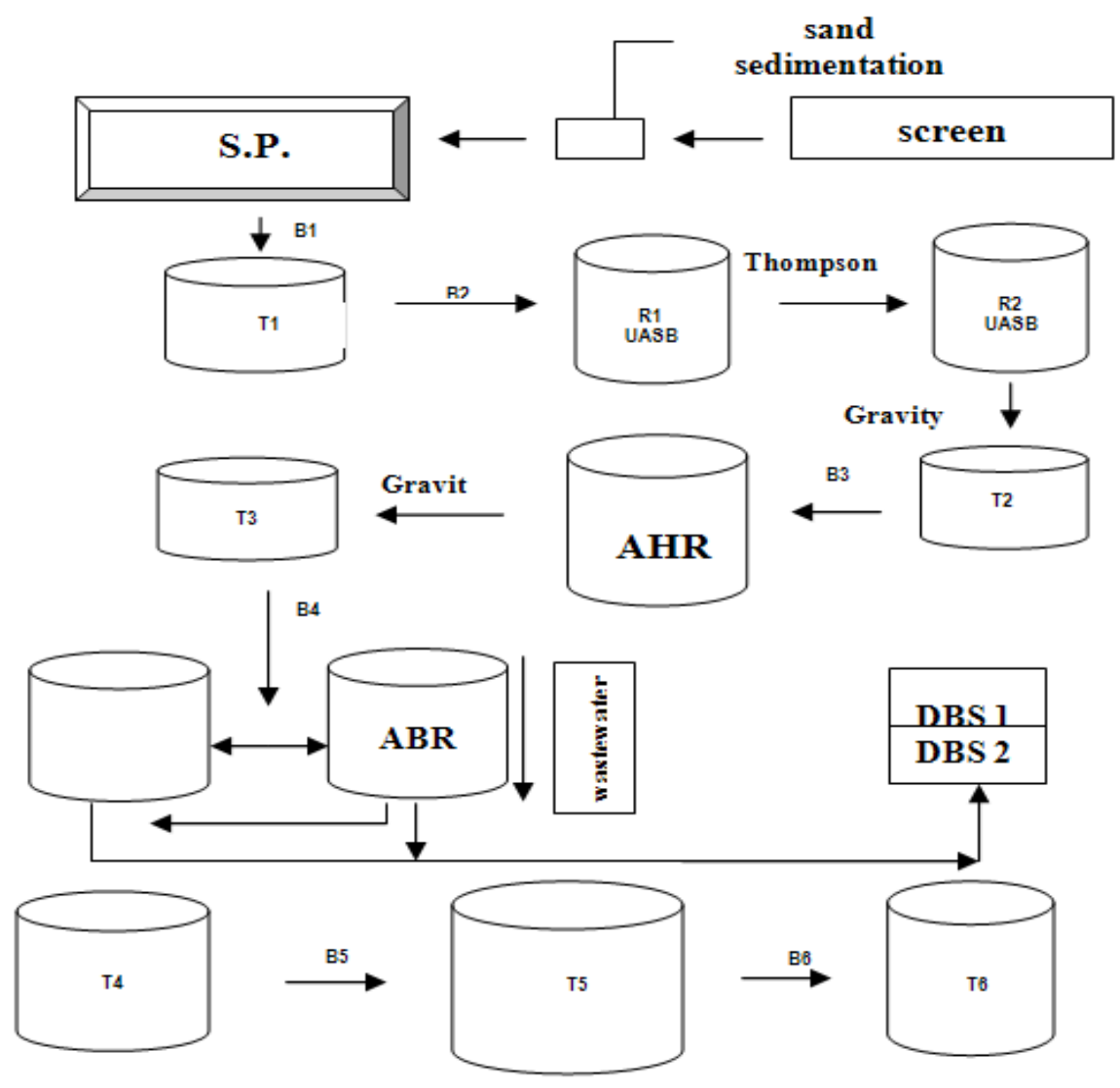

Figure 2 - Operational flowchart of the pilot system treating coffee wastewater.

\section{Epi-Fluorescence Microscopy}

To investigate the fluorescence of methanogenic archaeas, sludge samples of HAR's seventh port, counted from the top to the bottom, were diluted by $1 / 5$ with distilled water, pipetted on slides and taken for observation under epi-fluorescence microscope, Olympus, Model BX60.

\section{Scanning Electron Microscopy (SEM)}

Sludge samples of HAR's seventh port and also from the middle bracket (expanded clay, rolled pebble) were processed using a scanning electron microscopy (SEM), applying the following methodologies:

\section{Desiccation method}

This method was used to analyze only the samples of the seventh compartment digestion. Initially, the methodology used was as described by Pereira et al. (2009). The samples were immersed in liquid nitrogen at $-196^{\circ} \mathrm{C}$ and, once frozen, cut with a scalpel and mounted on the stubs coated with aluminum foil using double-sided tape (Fig. 4a). At room temperature, the sample returned to a liquid state and thereafter, the methodology was changed. The samples were dried in an oven at $70^{\circ} \mathrm{C}$ for two hours and then taken to a desiccator for $24 \mathrm{~h}$..

\section{Coverslip method}

Samples $( \pm 0.5 \mathrm{~mL})$ of the seventh compartment digestion were deposited on the glass slides with 1 $\mathrm{mm}$ thickness housed within a small Petri dish (Fig. 4b) and immersed in modified Karnovisky fixative $\quad(2.5 \%$ glutaraldehyde, $2 \%$ paraformaldehyde in $0.05 \mathrm{M}$ cacodylate buffer at 
$\mathrm{pH}$ 7.2) for one hour. They were then washed in cacodylate buffer solution three times for 10 minutes in order to remove the residual glutaraldehyde solution. In a protected environment (hood) six drops of osmium tetroxide were added for post-fixation. Petri dishes were wrapped with parafilm to keep the osmium gas. After four hours, the samples were washed three times in distilled water and then dehydrated in gradient of acetone three times for ten minutes (25, $50,75,90$ and $100 \%$ ) and then placed in open desiccator for $24 \mathrm{~h}$ for drying.

After drying, the samples were mounted on the stubs and transferred for the coverage of gold (sputter coater) in apparel brand BAL-TEC SCD050 model. The specimens were observed under the scanning electron microscope LEO brand, model EVO 40.

\section{Support material}

Samples of the support material, expanded clay and rolled pebble, were obtained by breaking up the pebbles in a conventional vise, while the expanded clay pellets were fragmented using a table vise. This procedure was necessary in order to be able to insert the samples into glass penicillin bottles with a modified Karnovsky's fixation solution. This was followed by the standard procedures for SEM (excluding the post-fixation with osmium tetroxide), and dehydrated in acetone, critical point drying, gold cover and observation.

\section{RESULTS AND DISCUSSION}

\section{Start up of the System and Steady State}

The parameters of the HAR in the study can be observed in the inoculation and in three matches during the monitoring in Table 1. Evidently the values were close in three start-ups for most of the observed parameters, except for $\mathrm{BOD}_{5}{ }^{20^{\circ} \mathrm{C}}$, which showed an increase, probably by the occurrence of solids washout out from the reactor. There was a reduction in the biological organic load rate (BOL) as a result of lower concentrations of $\mathrm{BOD}_{5}$, in the first start-up, about $310 \mathrm{mg} \mathrm{L}^{-1}$ and in the second start-up, dropped to $280 \mathrm{mg} \mathrm{L}^{-1}$. In the third startup, there was an increase of $18 \%$ at BOL, provided by the addition of coffee hulls in the pond in order to increase the organic matter present in it. The values of salinity, involving total dissolved solids (TDS) and electrical conductivity (EC) were increased around $70 \%$.

Table 1 - Parameters observed in the inoculation and the three matches held in the pilot system treating wastewater from wet coffee proccess, located in CCRCC / UFLA.

\begin{tabular}{lllll}
\hline Parameter & Inoculation & $\mathbf{1}^{\text {st }}$ start-up & $\mathbf{2}^{\text {nd }}$ start-up & $\mathbf{3}^{\text {rd }}$ start-up \\
\hline COD inf $\left(\mathrm{mg} \mathrm{L}^{-1}\right)$ & - & 828 & 665 & 645 \\
COD eff $\left(\mathrm{mg} \mathrm{L}^{-1}\right)$ & - & 310 & 280 & 380 \\
$\left.\mathrm{BOL}_{(\mathrm{kgBOD}} \cdot \mathrm{kgTVS}^{-1} \cdot \mathrm{d}^{-1}\right)$ & - & 0.0156 & 0,0103 & 0.01213 \\
$\mathrm{Xvt}(\mathrm{KgTVS})$ & - & 51.926 & 71.25 & 82.09 \\
$\mathrm{HRT}_{\text {HAR }}($ hour$)$ & - & 28.5 & 28.5 & 28.5 \\
$\mathrm{Q}_{\text {infl. }}\left(\mathrm{m}^{3} \mathrm{~d}^{-1}\right)$ & - & 2.62 & 2.62 & 2.62 \\
$\mathrm{OLR}_{\text {inf }}\left(\mathrm{Kg} \mathrm{BOD}_{5} \mathrm{~m}^{-3} \mathrm{~d}^{-1}\right)$ & - & 0.26 & 0.236 & 0.32 \\
$\mathrm{OLR}_{\text {inf }}\left(\mathrm{Kg} \mathrm{COD}_{5} \mathrm{~m}^{-3} \mathrm{~d}^{-1}\right)$ & - & 0.70 & 0.56 & 0.54 \\
$\mathrm{pH}_{\text {inf }}$ & 5,34 & 7.34 & 7.06 & 6.73 \\
$\mathrm{Temperature}_{\text {inf }}\left({ }^{\circ} \mathrm{C}\right)$ & 19,05 & 19.06 & 22.3 & 22.6 \\
$\mathrm{EC}_{\text {inf }}\left(\mathrm{dS} \mathrm{m}^{-1}\right)$ & 0,63 & 0.83 & 0.82 & 1.15 \\
$\mathrm{TDS}_{\text {inf }}\left(\mathrm{mg} \mathrm{L}^{-1}\right)$ & 507 & 645 & 640 & 903 \\
\hline
\end{tabular}

inf - Influent of HAR; eff- Effluent of HAR; Xvt- total volatile solids in each start-up.

\section{Evaluation System At Steady-State Conditions}

After three successive matches and after the transient period, the system was monitored daily to maintain the steady-state conditions. Aiming at increasing the biomass concentration in the reactor, it was decided to increase the volumetric organic loading rate (VOLR), increasing the flow and consequently decreasing the hydraulic retention time. Thus, in the $79^{\text {th }}$ day of operation, the rotations of the pumps 2 and 3 were increased from $1,000 \mathrm{rpm}\left(2.67 \mathrm{~m}^{3} \mathrm{~d}^{-1}\right.$ and $2.6 \mathrm{~m}^{3} \mathrm{~d}^{-1}$, respectively) to $1,060 \mathrm{rpm}\left(3.140 \mathrm{~m}^{3} \mathrm{~d}^{-1}\right)$ and 1,200 $\mathrm{rpm}\left(3.156 \mathrm{~m}^{3} \mathrm{~d}^{-1}\right)$, respectively, at $99^{\text {th }}$ day to $1,960\left(5.65 \mathrm{~m}^{3} \mathrm{~d}^{-1}\right)$ and $1,600 \mathrm{rpm}\left(4.13 \mathrm{~m}^{3} \mathrm{~d}^{-1}\right)$, 
respectively, affecting the volumetric organic loading rate (VOLR), which remained at this level until the end of experiment. These values are presented in Table 2.

Table 2 - Parameters analyzed at 79 and 99 days of monitoring pilot system treating wastewater from the coffee, located in CCRCC/ UFLA.

\begin{tabular}{lcc}
\hline Parameters & $\mathbf{7 9}^{\circ}$ Day & $\mathbf{9 9}^{\circ}$ day \\
\hline Rotation B3 $(\mathrm{rpm})$ & 1200 & 1600 \\
$\mathrm{Q}_{\mathrm{B} 3}\left(\mathrm{~m}^{3} \mathrm{~d}^{-1}\right)$ & 3.14 & 4,13 \\
$\mathrm{BOD}_{5}$ inf $\left(\mathrm{mg} \mathrm{L}^{-1}\right)$ & 31 & 14 \\
$\mathrm{COD}_{\text {inf }}\left(\mathrm{mg} \mathrm{L}^{-1}\right)$ & 195 & 58 \\
$\mathrm{BOL}_{\text {inf }}\left(\mathrm{kg} \mathrm{BOD}_{5} \mathrm{kgTVS}^{-1} \mathrm{~d}^{-1}\right)$ & 0.0014587 & 0.00099 \\
$\mathrm{HRT}_{\text {inf }}($ hours $)$ & 23.73 & 18.03 \\
$\mathrm{COV}_{\text {inf }}\left(\mathrm{kgBOD}_{5} \mathrm{~m}^{-3} \mathrm{~d}^{-1}\right)$ & 0.032 & 0.018 \\
$\mathrm{COV}_{\text {inf }}\left(\mathrm{kgCOD} \mathrm{m}^{-3} \mathrm{~d}^{-1}\right)$ & 0.199 & 0.077 \\
$\mathrm{X}_{\mathrm{vt}}$ inf $(\mathrm{kgSVT})$ & 66.77 & 58.3963 \\
\hline
\end{tabular}

inf - Influent of HAR; eff- Effluent of HAR; Xvt- total volatile solids in each start-up.

\section{EPI-Fluorescence Microscopy}

At the end of the experiment, only the last three compartments presented sludge: the number $6,7,8$ measuring $1.5 \mathrm{~m}$ from the base, representing $57 \%$ of the initial volume inoculated in the HAR. The samples were analyzed in epi-fluorescence microscopy. The analysis showed fewer bacteria in the material (dispersed biomass), confirming the low concentration of biomass at the end of the experiment. Bacteria could not be counted, as by Campos and Chernicharo (1991) in which, after the dilution, samples were placed in a haemocytometer chamber under fluorescent light for counting the methanogenic non-fluorescent and non-methanogenic. This situation was resulted as there was no ideal fit focus, due to the difficulty of adjustment between the camera and lens. In Figure 3 there are some images showing the autofluorescence of methanogenic archaea. This autofluorescence was due to the existence of specific coenzymes and cofactors such as coenzyme F420, coenzyme F430, coenzyme M, and methanoplerina methanofurano (Pereira et al. 2009).

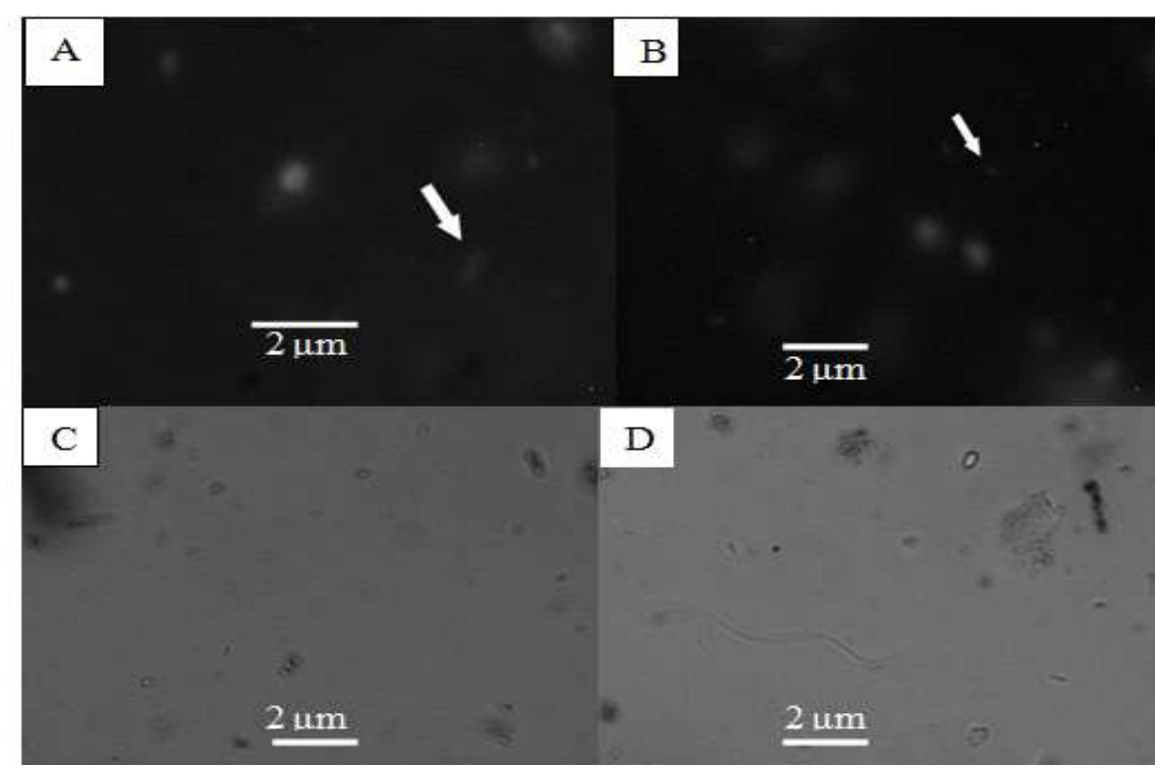

Figure 3 - Epifluorescence photomicrographs of samples of dispersed sludge digestion compartment 7 of the AHR, under fluorescent light (A,B) and under white light (C,D). Arrows indicate possible auto-fluorescent methanogenic archaea. 


\section{Scanning Electron Microscopy (SEM)}

The scanning electron microscopy was applied also to the support materials in order to verify the sludge adhered (biofilm), namely the attached biomass. The samples of $7^{\text {th }}$ digestion compartment were also analyzed for the dispersed biomass (sludge blanket). The samples had fewer bacteria, confirming the low concentration of biomass at the end of the experiment. The images produced using the technique of drying and methodology of mounting coverslips are shown in Figures 4, 5, 6 and 7. Some images showed cavities that could be considered the outputs of the bubbles of biogas. They also had fewer bacteria in

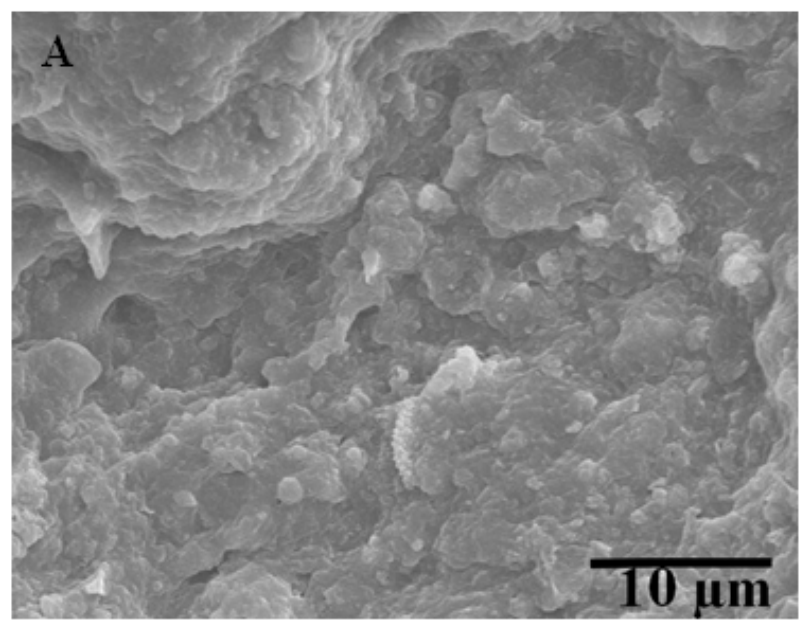

the biofilm, many fragments of inert material (because of the support defragmentation) and wastes from the bark of coffee.

The scanning electron microscopy images were obtained for the support materials using the technique of drying. Figure 6 showed that the gravel, due to its structure, presented, as a support material, less favorable to aggregation of bacteria and other elements. Expanded clay, on the other hand, being more porous, facilitated the adhesion of biomass and other organic and inorganic materials (Fig. 7). The sludge adhered to the support material also showed the growth of bacteria.

Figure 4 - Electron scanning of samples of the sludge spread of the 7th the digestion compartment of the HAR pilot system treating wastewater from coffee, located in CCRCC using the technique of drying (A) aspect of biomass in endogen process (B) presence of bacteria in the sludge dispersed. Arrow indicates bacteria.

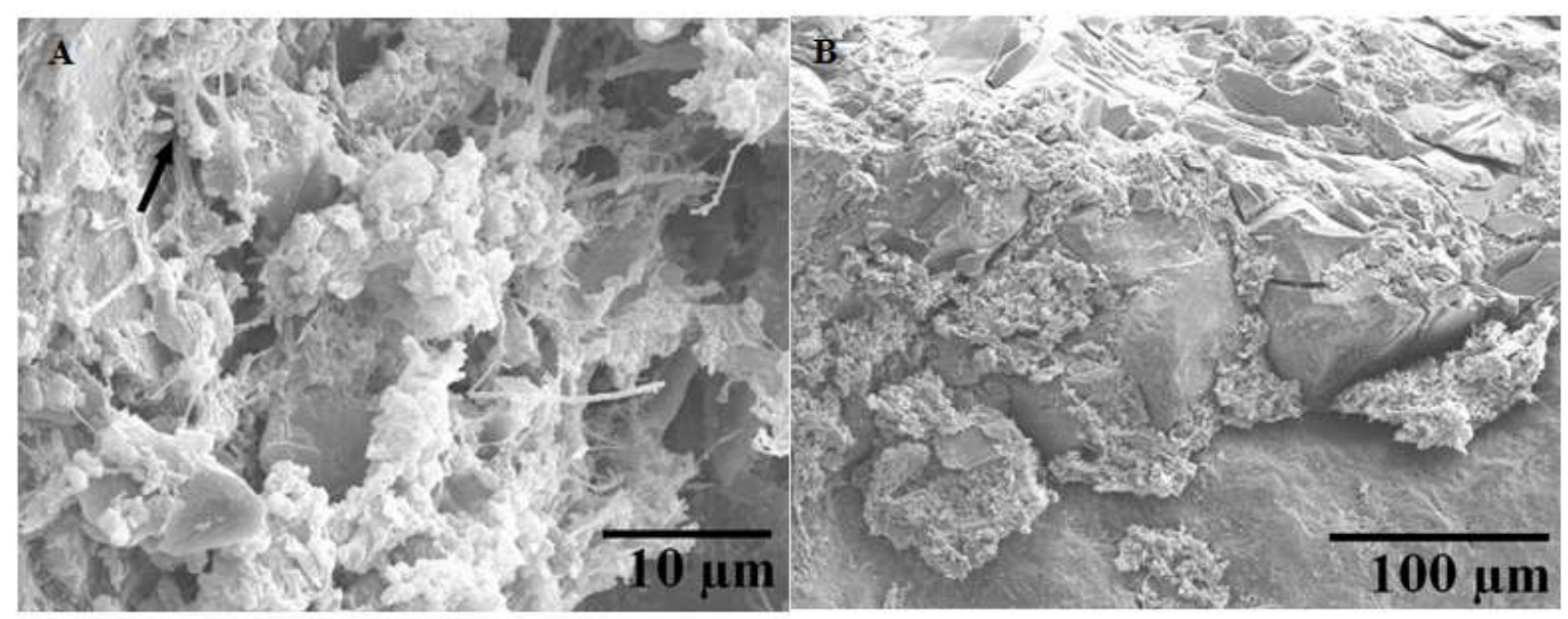

Figure 5 - Scanning Electron Microscope (SEM) photograph of samples of dispersed sludge from digestion compartment 7 of the HAR, using the technique of drying: (A) arrow indicates the residue of coffee pods scattered on the sludge, (B) arrow indicates possible release of bubbles of biogas. 

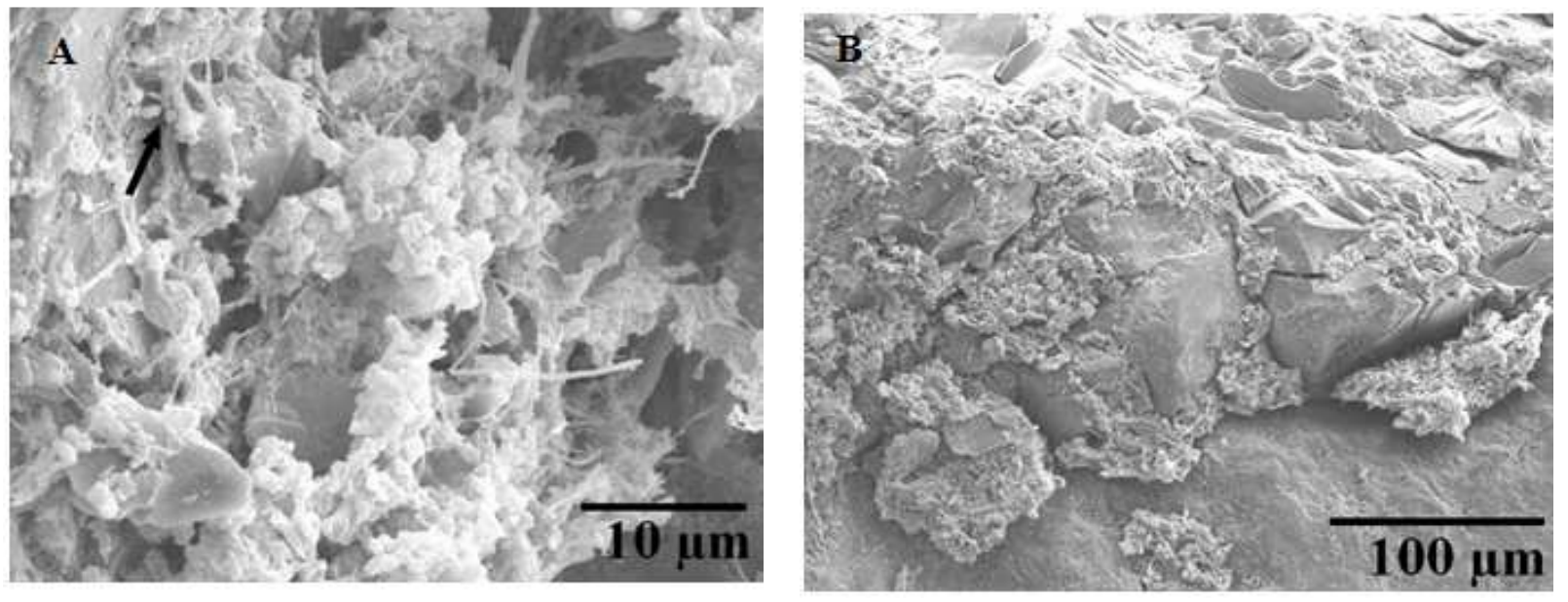

Figure 6 - Scanning Electron Microscope (SEM) photograph of sludge adhered to pebbles used as a medium of HAR: (A) presence of bacteria in the wells of gravel, (B) material that adheres to the surface of the pebble.

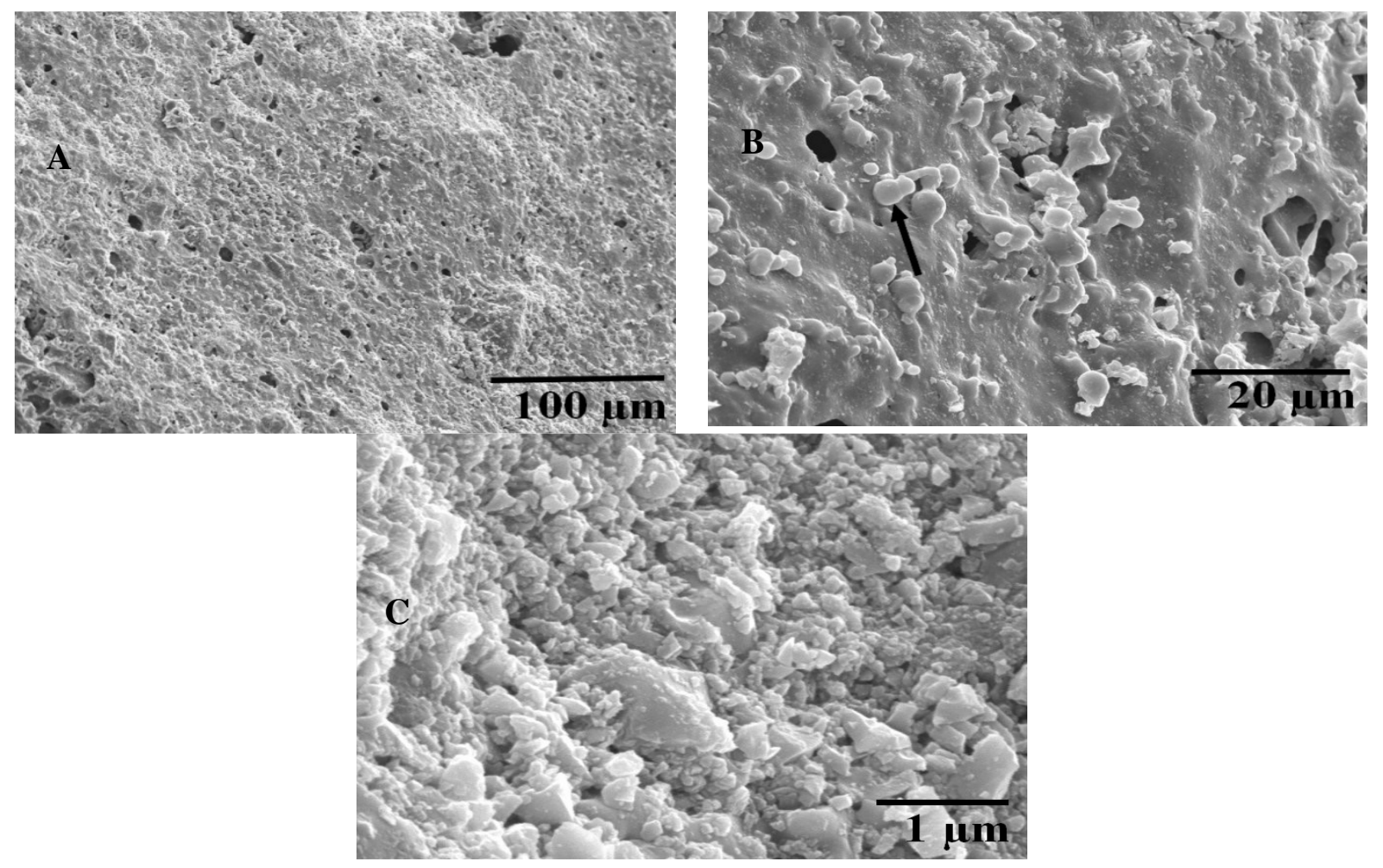

Figure 7 - Scanning Electron sludge adhered to the expanded clay used as a material of HAR: (A) surface of the expanded clay, (B) budding bacteria, (C) material that adheres to the surface of expanded clay.

The SEM micrographs showed that the outer surface of the expanded clay was smoother than the inner surface of the sample. The internal surface showed a higher amount of pores, without causing the interconnectedness of them. The higher porosity of the inner surface was related to the appearance of gas bubbles generated in the manufacturing process of expanded clay.

Fia et al. (2010) evaluated the influence of media type support on the efficiency of fixed bed 
anaerobic reactors (FBAR) treating coffee wastewater, with COD concentration of organic matter ranging between 812 and $5,320 \mathrm{mg} \mathrm{L}^{-1}$. The media used to immobilize the biomass were blast furnace slag, polyurethane foam and stone $\mathrm{n}^{\circ} 2$, with voids of 53, 48 and $95 \%$, respectively. The biofilm formed on all the supports showed the presence of different bacterial morphologies such as the bacilli, coconuts and filamentous. The bacilli were present in all the conditions studied; these were not fluorescent and had rounded contours, being similar to those of the genus Methanosaeta $s p$. There were also the cells similar to the genus Methanosarcina $s p$. in the reactor in which the slag was used as media support. The study used the reactors at high loading rates and did not evaluate the endogenia conditions, which justified the greatest diversity and quantity of morphologies observed when compared to this work. Fia et al. (2010) reported that the polyurethane foam presented the best COD efficiency of about $80 \%$. The authors attributed this result to the voids, which was greater than other medias, which also provided greater biomass retention quantified in terms of TVS (about 1,301 $\left.\mathrm{mg} \mathrm{g}^{-1}\right)$. In the present work, the expanded clay had higher porosity and showed higher aggregation of biomass and more morphological diversity. Fia et al. (2010) characterized the morphological diversity found along the height of the reactors (base, middle and top) for all the media under high loading rate, and therefore, had higher amount of morphological types of bacteria. Based on this, in this work the biomass of the $7^{\circ}$ compartment, at the top of the reactor, presented some bacteria of different morphologies and methanogenic, as shown in Figure 3. It could be possible that the HAR, due to the minifilters at the top, retained even under endogenia, large quantity of biomass within the reactor, enough to operate at low loading rate, and therefore, achieve high efficiencies as described by Silva et al. (2011). Probably, if there were low loading rate conditions on minifilters studied, no biomass would have been observed in the SEM and epi-fluorescence analysis.

\section{CONCLUSIONS}

The treatment units in the HAR resulted a loworganic loading causing in a decreased efficiency of the reactor. The expanded clay used as the support material in the internal minifilters proved to be more appropriate than the pebbles for biofilm attachment due to its higher roughness as well as because of its lower weight, which could help to reduce the cost of construction.

\section{ACKNOWLEDGEMENTS}

The authors are grateful to FAPEMIG within the program of Development Support for Agroindustrial Technological Innovation (EDT No. 013-23000-01) and $\mathrm{CNPq}$, for financial support without which it would be impossible to carry out this research project.

\section{REFERENCES}

APHA/AWWA/WEF Standard methods for the examination of water and wastewater. 21th. ed. Washington. D.C.: APHA - American Public Health Association; AWWA- American Water Works Association; WEF - Water Environment Federation., 2005.

Campos CMM, Chernicharo CAL. The use of the SMA-test for measuring toxicity in anaerobic sludges. Wat Sci Tech. 1991; 24 (2): 103-111.

Campos CMM, Prado MAC, Pereira EL. PhysicalChemical, Biochemical and Energetic characterization of wastewater origineted from wet coffee processing. Biosci J. 2010; 26 (2): 514-524.

Chaiprasert P, Suvajittanont W, Suraraksac B, Tanticharoend M, Bhumiratana S. Fibers as supporting media in anaerobic hybrid reactors: it's effects on system's performance and microbial distribution. Water Res. 2003; 37: 4605-4612.

Fia FRL, Borges AC, Matos AT, Duarte ICS, Fia R, Campos LC. Development of biofilm in anaerobic reactors treating wastewater from coffee grain processing. RBEAA-Agriambi. 2010; 14 (4): 210-217.

Omil F, Garrido JM, Arrojo B, Méndez R. Anaerobic filter reactor performance for the treatment of complex dairy wastewater at industrial scale. Water Res. 2003; 37: 4099-4108.

Pereira EL, Campos CMM, Moterani F. Avaliação do desempenho físico-químico de um reator UASB construído em escala piloto na remoção de poluentes de efluentes de suinocultura. Ambi-Água. 2010a; 5 (3): 79-88.

Pereira EL, Campos CMM, Moterani F. Effects of $\mathrm{pH}$, acidity and alkalinity on the microbiota activity of an anaerobic sludge blanket reactor (UASB) treating pig manure effluents. Ambi-Água. 2009; 4 (5): 157-168. 
Pereira EL, Campos CMM, Moterani F, Oliveira Neto AM. The efficiency of a sistem of anaerobic reactors treating swine wastewater. Acta Sci Tech, 2011; 33 (3): 287-293.

Pereira EL, Campos CMM, Moterani F. Physicalchemical and operational performance of an anaerobic baffled reactor (ABR) treating swine wastewater. Acta Sci Tech. 2010b; 32 (4): 399-405.

Prado MAC, Campos CMM. Biogas production in the treatment of Coffea arabica L. processing wastewaters in UASB anaerobic reactor for the potential use in the coffee drying. Ciênc Agrotec. 2008; 32: 938-947.

Silva JF, Campos CMM, Pereira EL, Silva VG. Microscopic evaluation of bacterial endogenia in concentric UASB reactors treating wastewater from wet process of coffee fruits. Acta Sci Tech, 2011a; 33 (2): 129-135.
Silva VG, Campos CMM, Silva JF, Almeida PH, Martins MA. Monitoring of physical, chemical, and biological parameters of a Hibrid Anaerobic Reactor (AHR) in pilot scale, treating wastewater from wet coffee production. Ciênc Agrotec. 2010; 34: 204-211.

Silva VG, Campos CMM, Pereira EL, Silva JF. Start-up and steady-state conditions of an Anaerobic Hybrid Reactor (AHR) using mini-filters composed with two types of support medium operating under low loading rates. Braz. Arch. Biol. Technol. 2011; 54: 973-982.

Torres P, Rodríguez JÁ, Uribe IE. Tratamiento de aguas residuales del proceso de extracción de almidón de yuca en filtro anaerobio: Influencia del medio soporte. Sci Tech. 2003; 23: 75-80.
Received: November 01, 2011; Revised: May 15, 2012; Accepted: February 15, 2013. 